\title{
Priority Education in European Countries: Comparative Conclusions
}

\author{
George Muskens*
}

\section{Binnenpad 24, Halsteren, The Netherlands}

\begin{abstract}
In the paper, the measures as applied in European countries are assessed that should enhance the chances of disadvantaged pupils and that of discriminated groups in European countries. First, the national target groups in seven countries are described, on behalf of national reports as well as comparative international databases. Then, the applicable measures are categorised as 'priority measures to enhance the individual chances of disadvantaged pupils' and as 'priority measures to fight the exclusion, segregation and discrimination of certain groups', in relation to national, regional, local and educational policy aims.
\end{abstract}

Most research on the measures and their effects consists of local case studies. Examples were discussed in the national reports and the preceding papers.

Promising measures are found in the case studies. These are reported. A general comparative conclusion is not allowed positive effects as observed on measures or cases cannot be generalised beyond their own frames, process and conditions. As far as such positive effects were observed, the conclusion can be and should be that it regards promising and interesting measures or cases that should help the relevant actors such as schools and school teams on the one side and the educational policymakers on the other to develop appropriate priority measures of their own.

Apart from this retained comparative conclusion one should keep in mind that 'Europe' has taken serious European responsibility for the fight against exclusion, segregation and discrimination, e.g. on behalf of article 149 of the European treaty and the Charter of Fundamental Rights of the European Union. The responsibility was underlined by the Grand Chamber of the European Court of Human Rights in its landmark judgement of 13 November 2007 against special Roma schools in the Czech Republic. Through the judgement, the European institutions are presumably forced to take direct responsibility against outplacement mechanisms towards special education on behalf of social or cultural grounds.

Keywords: Priority education, disadvantaged pupils, discriminated groups, measures, comparative assessment, European countries.

\section{THE FRAME OF PRIORITY EDUCATION}

The frame of priority education refers to educational measures that should enhance the chances, achievements and perspectives of disadvantaged pupils and groups of excluded, segregated or discriminated pupils in mainstream education. In most OECD-countries, the frame of priority education has been developed in the second half of the last century. Without these priority means and measures, disadvantaged and/or discriminated pupils would run the risk of failing in their educational career and to be excluded from schools for further education. In the UK, The Netherlands, the Scandinavian countries and in other countries too, it was acknowledged that children from lower socio-economic strata and/or children, who were not raised at home in a so-called 'elaborated' code, had less chance to attain the highest ranks of education. Their average achievement was too low in relation to talents and opportunities, as was proved in the classics of the sociology of education, such as Bernstein [1], Van Heek [2] and Bourdieu [3]. The countries acknowledged the disparities and inequities of their mainstream education, and decided to counter-act it more or less directly, by offering insertion classes, compensation means, measures

*Address correspondence to this author at the Binnenpad 24, Halsteren, The Netherlands; Tel: +31164686755 ; Fax: +31164683269;

E-mail: info@docabureaus.nl and incentives to schools and pupils. These 'priority means and measures' were aimed at the improved school achievement of the pupils, in accordance with their talents, and improved average achievements of compensated schools and their pupils. The 'priority means and measures' should also fight the exclusion, segregation or discrimination of pupils belonging to social and cultural minorities, enhancing intercultural understanding between different groups at the same time.

The first target groups for priority means and measures were the children from lower socio-economic strata ('working class') and children, whose parents were low on education, as an indicator of not being familiar with the elaborated codes of (higher) education and as an indicator on the lack of cultural capital in the family.

With the sharp increase in most Western European countries of the immigration of lowly educated workers, post-colonial citizens, asylum seekers, family re-unifiers, and 'illegal' immigrant minors ${ }^{1}$, immigrant children and

${ }^{1}$ On behalf of international charters and agreement all minors have to be educated, whether they are legal residents of the country or not. So, up to the age of adulthood, the illegal immigrant minors should be educated in mainstream education, as all other pupils. Countries may stop the financing 
families became a new and major target group of these priority means and measures. For an overview of research findings on immigrants and education I may refer to the recent synthesis of Friedrich Heckmann [5].

Further target groups were children belonging to indigenous minorities, particularly from Roma families and other travelling groups [6, 7]. It regards or regarded the countries with high numbers of indigenous minorities (Hungary, Slovenia, Spain, UK), or the countries that have given high priority to minority policies (Italy, Slovenia, Spain, Sweden) [8-12].

In relation to the seven preceding articles, the quantification of the national target groups of priority means and measures are given in Table $\mathbf{1}$ below. ${ }^{2}$

\section{TAILOR-MADE SUPPORT FOR INDIVIDUAL DISADVANTAGED PUPILS}

On the basis of the logics of means and ends, appropriate measures should be implemented that give tailor-made support to individual disadvantaged pupils [5, 17-20], e.g. through insertion classes, language courses, individual teaching, counselling and mentoring, special care, etc. The tailor-made support should educate them up to their full potentials, independent of the disparities that apparently keep them under that level, compared to other pupils, who are not struck by disadvantages and disparities. In addition to the measures mentioned, tailor-made support for immigrant and minority children may include 'home language classes', as high proficiency in the home language appears to be a support factor for learning other languages in general and the national language, or vice versa, under certain circumstances [16, 21-28].

In cases support as needed cannot be realised during the usual school time, the time of education might be extended. Examples regarded both the extended school day as well as pre-school years and courses during holidays for disadvantaged children or repeated classes and school years. Indirect ways in which educational careers might be extended regarded re-integration tracks and language courses for unemployed young people after their age of compulsory education, as the insertion classes in France and the integration courses in The Netherlands.

In addition to 'tailor-made support' of disadvantaged pupils, further measures may be implemented to support the schools, teachers and other relevant actors, in the field of training, expert support, or external co-operation and coordination with e.g. youth care, the judiciary, the local community, etc., as appropriate.

of their education and their access to their school on the day that they become an adult [4].

${ }^{2}$ For data on Germany, Poland and Sweden see [13-16]

${ }^{3}$ It is obvious that children of highly educated ex-patriates learn the elaborated codes of their parents first and then the elaborated codes of their new country and schools. Colloquial codes they may learn 'on the street'. Immigrant children and their parents often do not speak or write any elaborated code, and certainly not that of their country of origin. They speak 'restricted' Arabic, Turkish, Kurdish, Amazigh (Berber), etc. They are not helped by learning them 'elaborated' Arabic of Turkish. So, the axiom of learning the home language first needs at least some nuance and modification.
In Table 2 below the application of the measures per country is presented, on the reference sin the national reports.

\section{FIGHTING DISCRIMINATION}

In all countries, although in varying degrees, it was acknowledged that substantial minorities were segregated and discriminated, with direct and negative effects on their educational chances. In all countries, measures have been taken to fight discrimination, notwithstanding major objections that are expressed in public debate against such measures. ${ }^{4}$

The 'non-discrimination' measures regard at first the local Roma and Sinti communities as well as other travelling communities. They further regard national cultural and linguistic minorities, religious minorities, etc. [8-10]. Further: children with mental and/or physical challenges, bullied pupils, male or female pupils. It may regard the segregation processes in Western countries, cities, neighbourhoods and schools between well-to-do and educated 'white' people, on the one side, and poor immigrant and white classes, on the other - with the remark that such segregation is not necessarily the outcome of discriminatory choice for 'us' and against 'them', but that of market mechanisms that apparently offer the best houses, commodities, services and products to the more affluent classes. These may include the offer of 'best schools' on emerging educational markets, where the mainstream schools compete with other schools for pupils and funds. Educational market mechanisms were referred to in the national reports of France, Hungary, The Netherlands, Spain, and the UK. The preceding Dutch article is focussed on ethnic segregation. For most countries it regards a rather new phenomenon, ${ }^{5}$ which is related to the recognition and statefinancing of private schools, besides and in competition with public schools in local communities. The effect was the phenomenon of 'good white' and 'bad black' schools, as the schools were labelled, against all odds. ${ }^{6}$

${ }^{4}$ The issue of minority discrimination is a rather controversial issue in a number of countries, although not for principles that are stated in the European Human Rights Charter and in the national constitutions and laws. I may refer to three points that are raised in several countries 'against' priority measures for 'discriminated' groups. First point is that former discriminated minorities were no longer to be seen in that way, e.g. in relation to 'appropriate national legislation', national integration policies, home language policies and the introduction of regional autonomy, as in Spain and the UK. Second is that continued priority measures may reinforce the dependence of the groups and their young members upon public resources - the so-called 'victimisation' and 'hospitalisation' effects. Third is the occurring self-isolation and resistance against the 'majority culture' among minority groups, up to real or feared terrorism. The latter was related to violence in the seventies and eighties in e.g. Northern Italy, Basque regions, Northern Ireland and the Moluccan hijacks in The Netherlands. Presently the point regards mostly the (orthodox) Muslims, their clothing rules and terrorism as occurred in the US, UK, Spain, France, The Netherlands, Morocco, Turkey, Israel and Palestine, Iraq, Afghanistan, Indonesia. As INTMEAS-partners, we do not share the same opinion on these points, but we keep to the mission of the Fundamental Rights Agency of the EU with regard to fighting discrimination. See e.g. [10].

${ }^{5}$ Apart from the luxury boarding school for the super-rich.

${ }^{6}$ Segregation exists - see Peters \& Muskens, this volume. However, case studies, local statistics and achievement comparisons have revealed that the labels may be questionable [29]. 
Table 1. National Data and References on National Priority Groups: France, Hungary, Italy, The Netherlands, Slovenia, Spain, UK

\begin{tabular}{|c|c|c|c|c|c|}
\hline Indicators & $\begin{array}{c}\text { Class and/or } \\
\text { Neighbourhood } 7\end{array}$ & $\begin{array}{c}\text { Ethnicity: Immigrant } \\
\text { Minorities }^{8}\end{array}$ & $\begin{array}{l}\text { Ethnicity: Roma, } \\
\text { Sinti, Travellers }\end{array}$ & $\begin{array}{l}\text { Ethnicity: } \\
\text { Indigenous } \\
\text { Minorities }{ }^{10}\end{array}$ & Discrimination $^{11}$ \\
\hline France & $\begin{array}{l}253 \text { 'ambition } \\
\text { success areas' } \\
\text { with } 1738 \text { schools }\end{array}$ & $\begin{array}{c}370.000 \text { or } 5,9 \% \text { in p.e.; } \\
135.000 \text { in s.e. }\end{array}$ & $\begin{array}{l}\text { Roma pupils; no num- } \\
\text { bers }\end{array}$ & & $\begin{array}{c}\text { Systematic registration SIGNA } \\
\text { at } 709 \% \text { of the schools } \\
\text { Decrease of racist incidents since } \\
04 / 05 \\
\text { Resignation in relation 'list of } \\
\text { most violent schools' } \\
\text { Segregation as parents avoid } \\
\text { schools in priority zones }\end{array}$ \\
\hline Hungary & & Yes, Roma minority & $\begin{array}{l}400.000-600.000 \\
\text { Roma; 70.000 speak- } \\
\text { ers of Roma lan- } \\
\text { guages }\end{array}$ & $\begin{array}{c}200-220.000 \\
\text { German minority } \\
\text { /38.000 mother- } \\
\text { tongue, } \\
\text { Slovak, Croat, etc. } \\
\text { minorities (around } \\
10 \% \text { mother-tongue- } \\
\text { speakers) }\end{array}$ & $\begin{array}{l}\text { High on disparity for immigrant } \\
\text { and minority pupils } \\
\text { Roma discrimination and segre- } \\
\text { gation, Measures to reduce it } \\
\text { Parental freedom of school } \\
\text { choice encouraging segregation }\end{array}$ \\
\hline Italy & & $\begin{array}{c}413.000 \text { Non-Italians in p.e. } \\
\text { and s.e., } 43 \% \text { Non-EU, } \\
25 \% \text { from Africa } \\
\text { Also: Albania and Romania } \\
\text { Pre-p.e.: } 6,1 \% \\
\text { P.e.: } 7,1 \% \\
1 . s . e .: 6,7 \% \\
\text { u.s.e.: } 3,9 \%(7,9 \% \text { in u.v.e. }) \\
\end{array}$ & $\begin{array}{l}\text { 3500 Roma and Sinti, } \\
26.500 \text { dwellers }\end{array}$ & $\begin{array}{c}\text { French-, German, } \\
\text { Slovenian-, Friulian- } \\
\text {, Albanian-speaking } \\
\text { minorities }\end{array}$ & $\begin{array}{l}\text { Reported disparities for non- } \\
\text { Italian pupils }\end{array}$ \\
\hline $\begin{array}{l}\text { The Nether- } \\
\text { lands }\end{array}$ & $\begin{array}{l}\text { 2008: } 22 \% \\
\text { 2007: } 18 \% \\
\text { 2006: } 20 \%\end{array}$ & $\begin{array}{l}18 \% \text { in s.e.; highest in } \\
\text { lower streams and tracks } \\
250.000 \text { or } 15,1 \% \text { in p.e.; } \\
80.000 \text { or } 9,3 \% \text { in s.e. }\end{array}$ & Not to be registered & $\begin{array}{l}\text { Frisian minority; } \\
\text { Two further recog- } \\
\text { nised dialects of } \\
\text { standard Dutch }\end{array}$ & $\begin{array}{l}\text { Religious extremism in larger } \\
\text { cities } \\
\text { Right-wing extremism in the } \\
\text { county-side } \\
\text { Proved disparities for immigrant } \\
\text { and second generation pupils } \\
\text { Parental freedom of choice } \\
\text { encouraging segregation }\end{array}$ \\
\hline Slovenia & & $\begin{array}{l}\text { immigrant children not } \\
\text { speaking Slovenian }\end{array}$ & Roma children & $\begin{array}{l}\text { Hungarian-, Italian- } \\
\text { speaking minorities, } \\
\text { no deficiencies }\end{array}$ & $\begin{array}{l}\text { Direct and indirect discrimina- } \\
\text { tion of Roma pupils } \\
\text { Measures to reduce it }\end{array}$ \\
\hline Spain & & $\begin{array}{l}370.000 \text { or } 12,1 \% \text { in p.e.; } \\
70.000 \text { in s.e. } \\
\text { In } 20070,7 \text { million non- } \\
\text { Spanish immigrant children } \\
\text { in education; among these } \\
0,2 \text { million form EU-count- } \\
\text { ries and USA. }\end{array}$ & $\begin{array}{l}\text { 600-650.000 Gypsy / } \\
\text { Roma }\end{array}$ & $\begin{array}{l}\text { National languages } \\
\text { of the regions: } \\
\text { Basque/Euskadi, } \\
\text { Catalan, Galician, } \\
\text { Valencian }\end{array}$ & $\begin{array}{c}\text { Increasing numbers of immigrant } \\
\text { pupils at risk } \\
\text { Indirect discrimination of Roma } \\
\text { pupils [2] } \\
\text { Measures to reduce it }{ }^{12}\end{array}$ \\
\hline UK England & & $\begin{array}{l}\text { In p.e.: } 20,6 \% \text { ethnic } \\
\text { minority pupils } \\
480.000 \text { or } 13,8 \% \text { in p.e.; } \\
387.000 \text { or } 11,7 \% \text { in s.e. }\end{array}$ & $\begin{array}{l}6800 \text { Roma, Irish and } \\
\text { other travelling chil- } \\
\text { dren in p.e. } \\
\text { 3400 Roma, Irish and } \\
\text { other travelling chil- } \\
\text { dren in s.e. }\end{array}$ & & $\begin{array}{l}\text { Systematic registration at school } \\
\text { level; no national follow-up } \\
\text { Decreasing disparities for immi- } \\
\text { grant and second generation } \\
\text { pupils }\end{array}$ \\
\hline Uk Scotland & & $\begin{array}{l}2300 \text { asylum seeking and } \\
\text { refugee children }\end{array}$ & & & $\begin{array}{l}\text { Groups at risk: poor Muslims, } \\
\text { Roma and Travellers }\end{array}$ \\
\hline
\end{tabular}

Discrimination is an offense against the moral codes of the ten countries, in line with the treaties and Charters of the United Nations and the European Union. Therefore, it is to be counter-acted.

, as labels and labelling mechanisms usually are. Besides, 'black' is a fully wrong metaphor for immigrants and immigrant communities in Western Europe, as dark sub-Saharan African, Afro-Americans and Afro-Caribbeans represent a minority among all immigrants and immigrant communities, even in countries with high numbers of post-colonial immigrants from these regions. As a metaphor it reinforces the racist undertone of the debate on immigrants and integration in Western-European countries [4].

${ }^{7}$ (2009 August) National reports: 4. France, 6. Hungary, 7. Italy, 8. The Netherlands, 10. Slovenia, 11. Spain, 13. UK. Lepelstraat (DOCA Bureaus); retrieved from http://www.docabureaus.nl.
${ }^{8}$ Executive Agency Education, Audiovisual \& Culture. (2009). EURYDICE. Retrieved from Eurybase - Education systems in Europe: http://eacea.ec.europa.eu/education/eurydice/index_en.php; EURYDICE. (2009). Integrating immigrant children into schools in Europe. Communication with families and opportunities for mother tongue learning. Retrieved from www.eurydice.org ; National reports op cit.

${ }^{9}(2004)$. In M. Luciak, Migrants, minorities and education. Documenting discrimination and integration in 15 Member States of the European Union. Vienna: EUMC; (2005 January). Contempory status of minority education in the candidate countries. In M. Luciak, \& S. Binder, National strategies for minority schooling: a comparative analysis. Vienna: EUMC; National reports op cit.

${ }^{10}$ Ibid.; EURYDICE. (2005). Key data on teaching languages at school in Europe. EURYDICE. Retrieved from www.eurydice.org; national reports op cit.

11FRA European Union Agency for Fundamental Rights. (2007). Report on Racism and Xenophobia in the Member States of the EU. Vienna: FRA; National reports op. cit.

${ }^{12}$ The Spanish Ministry of Education does not agree with the FRA-report that referred to direct discrimination of Roma pupils in Spain. 
Table 2. Priority Measures for Fair and Best Chances in Seven EU-Countries

\begin{tabular}{|c|c|c|c|c|c|c|c|}
\hline & France & Hungary & Italy & The Netherlands & Slovenia & Spain & UK \\
\hline 1. Home language and culture measures & $\mathrm{X}$ & & $\mathrm{X}^{13}$ & $\mathrm{X}$ & $\mathrm{X}$ & $\mathrm{X}$ & $\mathrm{X}$ \\
\hline 2. Priority measures for pupils at risk & $\mathrm{X}$ & & $\mathrm{X}$ & $\mathrm{X}$ & $\mathrm{X}$ & $\mathrm{X}$ & $\mathrm{X}$ \\
\hline 3. Additional and individual teaching & $\mathrm{X}$ & $\mathrm{X}$ & $\mathrm{X}$ & $\mathrm{X}$ & $\mathrm{X}$ & $\mathrm{X}$ & $\mathrm{X}$ \\
\hline 4. Pre-school education & & $\mathrm{X}$ & $\mathrm{X}$ & $\mathrm{X}$ & $\mathrm{X}$ & $X$ & \\
\hline 5. Language education & $\mathrm{X}$ & & $\mathrm{X}$ & $\mathrm{X}$ & $\mathrm{X}$ & $X$ & $X$ \\
\hline 6. Insertion classes & $\mathrm{X}$ & & & $\mathrm{X}$ & & & \\
\hline 7. Extended school days & & $\mathrm{X}$ & $\mathrm{X}$ & $\mathrm{X}$ & & $\mathrm{X}$ & $\mathrm{X}$ \\
\hline 8. Further special classes and schools & & $\mathrm{X}$ & $\mathrm{X}$ & $\mathrm{X}$ & $\mathrm{X}$ & $\mathrm{X}$ & \\
\hline 9. Expertise measures & & $\mathrm{X}$ & $\mathrm{X}$ & $\mathrm{X}$ & $\mathrm{X}$ & $X$ & $\mathrm{X}$ \\
\hline 10. Networking and co-operation & $\mathrm{X}$ & $\mathrm{X}$ & $\mathrm{X}$ & $\mathrm{X}$ & & $X$ & $\mathrm{X}$ \\
\hline
\end{tabular}

As far as discrimination is the issue, other priority means and measures appear to be most appropriate compared to those used to counter-act socio-economic and other disadvantages, disparities and inequities. Discrimination itself is seen as a cause, and so discrimination itself is to be counter-acted, immediately and directly. Most appropriate measures may regard the collective empowerment and selforganisation of discriminated groups [30] as well as 'civics' or intercultural education for all $[28,31,32]$ and for teachers in particular [33]. Collective empowerment and self-organisation are referring both to actions from within the groups and to the national, international and regional recognition of minorities, e.g. by the way of linguistic minority rights, the right of minority education, or mixed community education $[13,26,34]$.

However, the same or similar measures that might be appropriate for individual tailor-made action may also be applied for anti-discriminatory purposes. Extra courses, classes, mentoring, counselling, etc. may serve empowerment and enrichment purposes, and therefore these may be appropriate measures $[35,36]$. Extended school days and school-time may also be applied as an appropriate antidiscriminatory measure, offering time for, e.g., extracurricular intercultural activities. The measures listed above for the support of teachers, schools and other relevant actors [training, networking, expertise, co-ordination and cooperation) may be useful both in the frame tailor-made individual action as in that of anti-discriminatory action. Without clear specifications of the foci it appeared to be hard to differentiate between the two lines of action. In this respect the relevant actors may keep to their own priorities.

In Table 3 below the application of these measures per country is presented.

\section{GIVING FAIR AND BEST CHANCES - PROMISING CASES}

In the national reports, case studies were discussed with regard to measures that have enhanced or should enhance

${ }^{13}$ Presently home language courses are part of temporary projects and cases. Their continuity is not assured fair and best chances for disadvantaged pupils at risk. In the preceding articles, a selection of cases was presented and assessed. In Table 4 below these cases are listed, while an evaluation of their usefulness and effectiveness is added.

Most cases in the articles proved to be promising. It means that they improved the chances of a specified target group of disadvantaged pupils at risk over a serious period of time, taking the local circumstances into consideration. They deserve the attention of national and regional policy makers as well as all further relevant actors in the field. The measures as applied could be applicable in other places as well, with similar positive effects, taking into consideration specific local adaptations and needs. Were possible, the measures were to be assessed in a comparative frame.

\section{NON-DISCRIMINATION MEASURES- PROMI- SING CASES}

Relevant case studies of non-discrimination measures are catalogued in Table $\mathbf{3}$ and listed in Table 5. There the evaluation of their usefulness and effectiveness is added.

Mutatis mutandis, the same conclusion can be drawn as above for the individual chances. That means: most cases that are mentioned proved to be promising. They diminished the exclusion of discriminated groups from mainstream education or diminished obvious local separation trends in education, taking the local circumstances into consideration. Therefore, they deserve the attention of national and regional policy makers as well as all further relevant actors in the field. The measures as applied could be applicable in other places as well, with similar positive effects, taking into consideration specific local adaptations and needs. Were possible, the measures were to be assessed in a comparative frame.

\section{COMPARATIVE CONCLUSION}

A sincere amount of proof on the value of priority education measures is delivered. It is certainly convincing at the case level. It has shown that at places, where disadvantaged pupils were supported by priority measures or at places at considerable risk of educational segregation and discrimination, remarkable progress was observed. Progress meant, in case, e.g.: 
Table 3. Priority Measures for Non-Discrimination in Seven EU Countries

\begin{tabular}{|c|c|c|c|c|c|c|c|}
\hline & France & Hungary & Italy & The Netherlands & Slovenia & Spain & UK \\
\hline 1. Home language and culture measures & & $\mathrm{X}$ & $\mathrm{X}$ & $\mathrm{X}^{16}$ & $\mathrm{X}$ & $\mathrm{X}$ & $\mathrm{X}$ \\
\hline 2. Legislation, mainstreaming against discrimination & $\mathrm{X}$ & $\mathrm{X}$ & $\mathrm{X}$ & $\mathrm{X}$ & $\mathrm{X}$ & $\mathrm{X}$ & $\mathrm{X}$ \\
\hline 3. Neighbourhood and community development & $\mathrm{X}$ & & $\mathrm{X}$ & $\mathrm{X}$ & $\mathrm{X}$ & $\mathrm{X}$ & \\
\hline 4. Access rules & $\mathrm{X}$ & $\mathrm{X}$ & $\mathrm{X}$ & $\mathrm{X}$ & $\mathrm{X}$ & & $\mathrm{X}$ \\
\hline 5. Parents' participation & $\mathrm{X}$ & & $\mathrm{X}$ & $\mathrm{X}$ & $\mathrm{X}$ & $\mathrm{X}$ & $\mathrm{X}$ \\
\hline 6. Extended school days & & $\mathrm{X}$ & $\mathrm{X}$ & & & $\mathrm{X}$ & $\mathrm{X}$ \\
\hline 7. Expertise measures & $\mathrm{X}$ & $\mathrm{X}$ & $\mathrm{X}$ & $\mathrm{X}$ & $\mathrm{X}$ & $\mathrm{X}$ & $\mathrm{X}$ \\
\hline 8. Networking and co-operation & $\mathrm{X}$ & $\mathrm{X}$ & $\mathrm{X}$ & $\mathrm{X}$ & $\mathrm{X}$ & $\mathrm{X}$ & $\mathrm{X}$ \\
\hline 9. Intercultural education & $\mathrm{X}$ & $\mathrm{X}$ & $\mathrm{X}$ & & $\mathrm{X}$ & $\mathrm{X}$ & $\mathrm{X}$ \\
\hline 10. Other measures & & $\mathrm{X}$ & $\mathrm{X}$ & & $\mathrm{X}$ & & \\
\hline
\end{tabular}

- $\quad$ Shared satisfaction among relevant actors such as pupils, parents, teachers, school-leaders, experts, policy makers, etc.,

- Better images of the 'others' in majority-minority relations,

- Better school climate,

- $\quad$ New mixed schools or newly mixed schools that were segregated in the past,

- Improved local relations and less 'racial' incidents as portrayed in the media,

- Extra-ordinary learning gain as measured in the course of 'priority time',

- Improved linguistic capacities,

- Higher marks for mathematics, science and other important subjects, ${ }^{14}$

- Diminished early school leaving and higher secondary school achievements, ${ }^{15}$

- $\quad$ Etc.

Comparative proof and proof that should follow from statistical time series is, however, not convincing. Successstories at the one place or school appeared sometimes to be also a success-story at most other places and schools, particularly with regard to specialised support staff such as Roma assistants and/or voluntary (student) tutors and mentors from the 'own' group, but success appeared not to be guaranteed. The success-stories are most convincing arguments in debate on the necessity and urgency of priority measures in education in relation to inequities and/or discrimination as observed and as to be counter-acted.

Other successful 'pilots' could hardly be replicated at other places and schools, without major adaptations to local

${ }^{14}$ These marks are assessed comparatively for most OECD-countries by TIMMS and PISA OECD. [37, 38].

${ }^{15}$ Comparative trends are published by EUROSTAT on a yearly basis [39, 40].

${ }^{16} \mathrm{On}$ a voluntary and extra-curricular basis, as offered e.g. by selforganisations. people and circumstances. Apparently, a successful pilot or some successful cases are not full and convincing proof for further measures and action. Often, lessons are to be learnt and adaptations to be made. ${ }^{17}$ Failing 'pilots' and pilots that could not be replicated easily may work out as arguments against priority measures in education. It will need a major comparative research effort to prove the effectiveness and wide applicability of measures to give fair and best chances to disadvantaged pupils at risk or to diminish discrimination and separation trends in education. It regards a monks' effort, consisting of the progressive comparative assessment of more and more cases, regional, national and international. Our research project and the INCLUD-ED project led by Ramón Flecha of Barcelona University [42] represent a first result of the comparative assessment of good practices. Further progress may follow. I think that the process is helped by regional, national and European of international expert centres or clearing systems of good inclusive practices. Therefore, I have recommended the establishment of such expert centres or clearing systems in the report [43].

Statistical time series have delivered convincing proof in all countries concerned on inequities and segregation or discrimination, as these emerged and changed or disappeared over time. Proof regarded the prevalence on indicators of inequities, disadvantaged, segregation and/or discrimination, not the causes. They did not show, neither, in how far certain measures were leading to changed rates and figures on the indicators, i.e. had effects. Politicians have stated that they expected that their policies and measures would change the indicators in a positive direction. However, so far the changes were not observed or observed changes could not be related to policies and measures.

The general conclusion then is that there is no convincing proof with regard to priority measures in education beyond the level of success-stories. People and their schools make the successes: committed school-leaders and teachers, supporting specialists/volunteers, expert advisers, parents etc.

${ }^{17}$ In the paper read at the ECER Conference in Vienna, 30 September 2009, I have argued that controlled comparative experiments are infeasible in educational practice [41]. 
Table 4. Priority Measures for Fair and Best Chances in Seven EU-Countries

\begin{tabular}{|c|c|c|c|}
\hline Country & Case(s) & Measure(s) & Evaluation \\
\hline France & 1. Regional priority areas (so-called ZEP) & $\begin{array}{l}\text { 2. Priority measures for pupils at risk } \\
\text { 3. Additional and individual teaching } \\
\text { 5. Language education } \\
\text { 6. Insertion classes }\end{array}$ & $\begin{array}{l}\text { Promising cases, but controversial } \\
\text { as achievements were not im- } \\
\text { proved, on the average. }\end{array}$ \\
\hline \multirow{4}{*}{ Hungary } & 1. Free meals in Kindergarten & 4. Pre-school education & Unclear \\
\hline & 2. Repeated classes & $\begin{array}{l}\text { 7. Extended school days } \\
\text { 8. Further special classes and schools }\end{array}$ & Controversial \\
\hline & 3. From the last bench & $\begin{array}{l}\text { 7. Extended school days } \\
\text { 9. Expertise measures }\end{array}$ & Promising \\
\hline & $\begin{array}{l}\text { 4. National Development Plan II 2007- } \\
2013\end{array}$ & $\begin{array}{l}\text { 2. Priority measures for pupils at risk } \\
\text { 9. Expertise measures }\end{array}$ & To be assessed \\
\hline \multirow{2}{*}{ Italy } & $\begin{array}{l}\text { 1. Several regional projects for widening } \\
\text { and deepening educational competence }\end{array}$ & 9. Expertise measures & $\begin{array}{l}\text { Urgently desirable and indispen- } \\
\text { sable }\end{array}$ \\
\hline & $\begin{array}{l}\text { 2. Regional actions aimed at fostering } \\
\text { Italian language competence }\end{array}$ & 5. Language education & $\begin{array}{c}\text { Satisfactory, but fragile (no guar- } \\
\text { anteed continuity) }\end{array}$ \\
\hline $\begin{array}{l}\text { The Nether- } \\
\quad \text { lands }\end{array}$ & $\begin{array}{l}\text { 1. Best achievement at primary school } \\
\text { Mozaiek }\end{array}$ & $\begin{array}{l}\text { 2. Priority measures for pupils at risk } \\
\text { 3. Additional and individual teaching } \\
\text { 5. Language education } \\
\text { 9. Expertise measures }\end{array}$ & Promising \\
\hline \multirow{3}{*}{ Slovenia } & 1. Homogenous Roma classes & 1. Home language and culture measures & $\begin{array}{l}\text { Not effective; No further legal basis } \\
\text { since } 2003 / 2004\end{array}$ \\
\hline & $\begin{array}{l}\text { 2. Partly homogenous classes: Roma } \\
\text { children and others }\end{array}$ & $\begin{array}{l}\text { 1. Home language and culture measures } \\
\text { 3. Additional and individual teaching } \\
\text { 5. Language education } \\
\text { 9. Expertise measures } \\
\end{array}$ & $\begin{array}{l}\text { Special Roma hours for many } \\
\text { subjects; apparently effective in } \\
\text { some cases }\end{array}$ \\
\hline & $\begin{array}{l}\text { 3. Heterogenous classes: Roma and non- } \\
\text { Roma children together }\end{array}$ & $\begin{array}{l}\text { 1. Home language and culture measures } \\
\text { 3. Additional and individual teaching } \\
\text { 5. Language education } \\
\text { 9. Expertise measures }\end{array}$ & $\begin{array}{c}\text { Most promising, particularly at the } \\
\text { beginning of the school career of } \\
\text { Roma children - Kindergarten, } \\
\text { primary schools }\end{array}$ \\
\hline \multirow{2}{*}{ Spain } & $\begin{array}{l}\text { 1. The Brudila Callí project: overcoming } \\
\text { the truancy and school failure of Roma } \\
\text { girls and adolescents }\end{array}$ & $\begin{array}{l}\text { 1. Home language and culture measures } \\
\text { 2. Priority measures for pupils at risk } 3 \text {. Addi- } \\
\text { tional and individual teaching } \\
\text { 9. Expertise measures } \\
\text { 10. Networking and co-operation }\end{array}$ & $\begin{array}{c}\text { Promising - new capacities and } \\
\text { employment for the women in- } \\
\text { volved }\end{array}$ \\
\hline & $\begin{array}{l}\text { 2. WORKALÓ project: creating new } \\
\text { occupational opportunities for gypsies }\end{array}$ & $\begin{array}{l}\text { 1. Home language and culture measures } \\
\text { 2. Priority measures for pupils at risk } 3 \text {. Addi- } \\
\text { tional and individual teaching } \\
\text { 9. Expertise measures } \\
\text { 10. Networking and co-operation }\end{array}$ & $\begin{array}{l}\text { Promising - new capacities and } \\
\text { employment for the gypsies in- } \\
\text { volved }\end{array}$ \\
\hline \multirow{6}{*}{$\boldsymbol{U} \boldsymbol{K}$} & $\begin{array}{l}\text { 1. Mentoring ('buddy') systems (children } \\
\text { of refugees and asylum seekers) }\end{array}$ & 3. Additional and individual teaching & Good effects were reported \\
\hline & $\begin{array}{l}\text { 2. Designated teachers, specialised staff } \\
\text { (children of refugees and asylum seekers) }\end{array}$ & $\begin{array}{l}\text { 3. Additional and individual teaching } \\
\text { 9. Expertise measures }\end{array}$ & $\begin{array}{l}\text { Good at points, but also points that } \\
\text { need further attention and } \\
\text { improvement }\end{array}$ \\
\hline & $\begin{array}{l}\text { 3. Staff development (children of refugees } \\
\text { and asylum seekers) }\end{array}$ & 9. Expertise measures & $\begin{array}{l}\text { Good at points, but also points that } \\
\text { need further attention and } \\
\text { improvement }\end{array}$ \\
\hline & $\begin{array}{l}\text { 4. ICT for contact and learning support } \\
\text { (children of Gypsy/Travellers) }\end{array}$ & $\begin{array}{l}\text { 9. Expertise measures } \\
\text { 10. Networking and co-operation }\end{array}$ & $\begin{array}{l}\text { Is recommended on the basis of } \\
\text { assessment }\end{array}$ \\
\hline & $\begin{array}{l}\text { 5. Materials and information for parents } \\
\text { (children of Gypsy/Travellers) }\end{array}$ & $\begin{array}{l}\text { 9. Expertise measures } \\
\text { 10. Networking and co-operation }\end{array}$ & $\begin{array}{l}\text { Is recommended on the basis of } \\
\text { assessment }\end{array}$ \\
\hline & $\begin{array}{l}\text { 6. Integrated services (children of } \\
\text { Gypsy/Travellers) }\end{array}$ & 10. Networking and co-operation & $\begin{array}{l}\text { Is recommended on the basis of } \\
\text { assessment }\end{array}$ \\
\hline
\end{tabular}

They may find and get facilities as available in the frame of national or regional priority education, adapting these to their people and circumstances. In this frame top-down measures would badly fit. Such measures may explain part of the failing proof with regard to positive effects of priority measures. They may have gone lost in educational and school routines, lack of time and attention, resistance to change, displacement of goals, and other NIMBYmechanisms.
At one point, the European domain concerning priority measures in education has surpassed the scope ands scale of applicable measures and that of comparative research. It regards the basic rejection of discrimination in education. It regards the fundamental rejection of discrimination in the Charter of the European Union. For the educational domain, the rejection was underlined by the landmark judgement of the European Court of Human Rights of 13 November 2007 [44]. The Court ruled aigainst special Roma schools. In no European country 
Table 5. Priority Measures for Non-Discrimination in Seven EU-Countries

\begin{tabular}{|c|c|c|c|}
\hline Country & Case(s) & Measure(s) & Evaluation \\
\hline France & $\begin{array}{l}\text { 1. The French mainstream model to deal } \\
\text { with diversity }\end{array}$ & $\begin{array}{l}\text { 2. Legislation, mainstreaming against discrimination } \\
\text { 3. Neighbourhood and community development } \\
\text { 4. Access rules } \\
\text { 5. Parents' participation } \\
\text { 7. Expertise measures } \\
\text { 8. Networking and co-operation }\end{array}$ & Emerging alternative solutions \\
\hline \multirow{3}{*}{ Hungary } & $\begin{array}{l}\text { 1. Roma class assistants, "family co- } \\
\text { ordinators" }\end{array}$ & $\begin{array}{l}\text { 1. Home language and culture measures } \\
\text { 7. Expertise measures } \\
\text { 8. Networking and co-operation } \\
\text { 9. Intercultural education }\end{array}$ & $\begin{array}{l}\text { Promising but not further } \\
\text { implemented }\end{array}$ \\
\hline & 2. School choice restrictions & 4. Access rules & Not yet assessed \\
\hline & $\begin{array}{l}\text { 3. National Network of Integration in } \\
\text { Education }\end{array}$ & $\begin{array}{l}\text { 7. Expertise measures } \\
\text { 8. Networking and co-operation }\end{array}$ & Not yet assessed \\
\hline \multirow{2}{*}{ Italy } & $\begin{array}{l}\text { 1. Regional intercultural events and } \\
\text { manifestations }\end{array}$ & $\begin{array}{l}\text { 1. Home language and culture measures } \\
\text { 8. Networking and co-operation } \\
\text { 9. Intercultural education } \\
\text { 10. Other measures }\end{array}$ & Promising \\
\hline & $\begin{array}{l}\text { 3. Regional projects aimed at supporting } \\
\text { and reinforcing processes of inclusion of } \\
\text { foreign citizens }\end{array}$ & $\begin{array}{l}\text { 8. Networking and co-operation } \\
\text { 9. Intercultural education } \\
\text { 10. Other measures }\end{array}$ & Promising \\
\hline \multirow{3}{*}{$\begin{array}{l}\text { The } \\
\text { Netherlands }\end{array}$} & 1. Local 'zoned access' rules & $\begin{array}{c}\text { 4. Access rules } \\
\text { 5. Parents' participation } \\
\text { 8. Networking and co-operation }\end{array}$ & $\begin{array}{l}\text { Feasible in the local context (no } \\
\text { opposition) }\end{array}$ \\
\hline & $\begin{array}{l}\text { 2. Local 'gambling machine' concerning } \\
\text { school choice }\end{array}$ & $\begin{array}{c}\text { 4. Access rules } \\
\text { 5. Parents' participation } \\
\text { 8. Networking and co-operation }\end{array}$ & $\begin{array}{l}\text { Feasible in the local context (no } \\
\text { opposition) }\end{array}$ \\
\hline & $\begin{array}{l}\text { 3. Local parental initiative to stop 'white } \\
\text { flight' }\end{array}$ & $\begin{array}{l}\text { 5. Parents' participation } \\
\text { 8. Networking and co-operation }\end{array}$ & Promising in the local context \\
\hline Slovenia & $\begin{array}{l}\text { 1. Heterogeneous classes: Roma and } \\
\text { non-Roma children together }\end{array}$ & $\begin{array}{l}\text { 1. Home language and culture measures } \\
\text { 3. Neighbourhood and community development } \\
\text { 5. Parents' participation } \\
\text { 9. Expertise measures } \\
\text { 10. Networking and co-operation } \\
\end{array}$ & $\begin{array}{l}\text { Most promising, particularly at the } \\
\text { beginning of the school career of } \\
\text { Roma children - Kindergarten, } \\
\text { primary schools }\end{array}$ \\
\hline Spain & $\begin{array}{l}\text { 2. WORKALÓ project: creating new } \\
\text { occupational opportunities forr gyspsies }\end{array}$ & $\begin{array}{l}\text { 1. Home language and culture measures } \\
\text { 3. Neighbourhood and community development } \\
\text { 5. Parents' participation } \\
\text { 7. Expertise measures } \\
\text { 8. Networking and co-operation } \\
\end{array}$ & Promising \\
\hline \multirow{4}{*}{$U K$} & $\begin{array}{c}\text { 1. Integrated services (children of } \\
\text { Gypsy/Travellers) }\end{array}$ & 8. Networking and co-operation & $\begin{array}{l}\text { Is recommended on the basis of } \\
\text { assessment }\end{array}$ \\
\hline & $\begin{array}{l}\text { 2. Gaelic-, Welsh- and Irish-medium } \\
\text { language teaching (Minority language } \\
\text { speakers) }\end{array}$ & $\begin{array}{l}\text { 1. Home language and culture measures } \\
\text { 7. Expertise measures }\end{array}$ & Promising in the local context \\
\hline & $\begin{array}{l}\text { 3. Online resources, information and } \\
\text { guidance for teachers (Minority } \\
\text { language speakers) }\end{array}$ & $\begin{array}{l}\text { 7. Expertise measures } \\
\text { 8. Networking and co-operation }\end{array}$ & $\begin{array}{l}\text { Is recommended on the basis of } \\
\text { assessment }\end{array}$ \\
\hline & $\begin{array}{l}\text { 4. Pre-service and in-service support for } \\
\text { teachers (Minority language speakers) }\end{array}$ & 7. Expertise measures & $\begin{array}{c}\text { Is recommended on the basis of } \\
\text { assessment }\end{array}$ \\
\hline
\end{tabular}

this practice can be accepted further on. The Commission staff is working out the implications of this landmark judgement [12]. The author has recommended that the EU should take up its apparent responsibility in this respect, and should take up statutory responsibility for the discriminatory special Roma schools and eventually also for such schools for children from other social and cultural minorities.

\section{ACKNOWLEDGMENT}

None declared.

\section{CONFLICT OF INTEREST}

None declared.

\section{REFERENCES}

[1] Bernstein B. Class, codes and control (three volumes). London: Routledge and Kegan Paul; 1971-1975. 
[2] Heek F. v. Het verborgen talent: milieu, schoolkeuze en schoolgeschiktheid [The hidden talent: class, school choice and suitability for school. Meppel: Boom; 1968.

[3] Bourdieu P., Passeron J-C. Reproduction in education, society, and culture (second edition). Thousand Oaks CA: Sage; 1990.

[4] Muskens G. The case of the Netherlands. In: Aumüller J, editor. Immigrant generations and the problem of measuring integration - a European comparison. Berlin: Edition Parabolis; 2007. p. 99-236.

[5] Heckmann F. Education and migration. Strategies for integrating migrant children in European schools and socities. A synthesis of research findings for policy-makers. Bamberg: University of Bamberg 2008 April [NESSE Report].

[6] Cluster "Access and Social Inclusion in Lifelong Learning". (De)segregation in education. Summary report of the Peer Learning Activity in Hungary, 25-27 April 2007. [Knowledge System for Lifelong Learning, www.kslll.net/PeerLearningActivity, retrieved on 20096 May].

[7] Farkas L. Segregation of Roma children in education. Addressing structural discrimination through the Race Equality Directive. Brussels: European Commission 2007 July.

[8] Contempory status of minority education in the candidate countries. In: Luciak M., Binder S., editors. National strategies for minority schooling: a comparative analysis. Vienna: EUMC; 2005 January.

[9] Luciak M. Migrants, minorities and education. Documenting discrimination and integration in 15 Member States of the European Union. Vienna: EUMC 2004.

[10] FRA European Union Agency for Fundamental Rights. Report on Racism and Xenophobia in the Member States of the EU. Vienna: FRA 2007.

[12] European Commission. Working document accompanying 'Nondiscrimination and equal opportunities: a renewed commitment. Community instruments and policies for Roma inclusion. Brussels: European Commission 2008 July 2 SEC(2008) 2172.

[13] Dingu-Kyrklund E. Inclusion and education in European countries. Final report: 12. Sweden. Lepelstraat: DOCA Bureaus 2009 August.

[14] Muskens G. Inclusion and education in European countries. Final report: 2. Comparative conclusions. Lepelstraat: DOCA Bureaus 2009 August.

[15] Federowicz M, Sitek M. Inclusion and education in European countries. Final report: 9. Poland. Lepelstraat: DOCA Bureaus 2009 August.

[16] Gogolin I, Jochum C. Inclusion and education in European countries. Final report: 5. Germany. Lepelstraat: DOCA Bureaus 2009 August.

[17] Cluster "Access and Social Inclusion in Lifelong Learning". Fight against failure at school and inequality in education. Summary report of the Peer Learning Activity in Paris, 12-15 November 2007. [Knowledge System for Lifelong Learning, www.kslll.net/Peer Learning Activities, retrieved on 2009 May 06].

[18] Cluster "Access and Social Inclusion in Lifelong Learning". Positive discrimination measures, school integration of immigrant children, support to school drop-out. Summary report of the Peer Learning Activity in Brussels, 9-11 October 2006. [Knowledge System for Lifelong Learning, kslll.net/PeerlearningActivities, retrieved on 2009 May 06].

[19] European Commission. Green paper. Migration \& mobility: challenges and opportunities for EU education systems COM(2008) 423 Final. Brussels: European Commission 2008 July 03.

[20] Commission staff. Migration and mobility: challenges and opportunities for the EU education system. Brussels: European Commission2008 July 3.

[21] Ager D, Muskens G, Wright S, eds. Language education for intercultural communication. Clevedon: Multilingual Matters 1993.

[22] Extra G. Verhoeven L. Bilingualism and migration. Berlin-New York: Walter de Gruyter 1998.

[23] Gogolin I. Linguistic and Cultural Diversity in Europe: a challenge for educational research and practice. Euro Educ Res J 2002; 1(1): 123-38.

[24] Grima A.C. Promoting linguistic diversity and whole-school development. Strasbourg: Council of Europe Publishing 2007.
[25] Idiazabal I, Amorrortu E, Barreña A, et al. eds. Mother tongue, language of immersion. What can the school do to revitalize minorized languages? XIIth conference of the Foundation for Endangered Languages.

[26] Necak Lük A. Novak Lukanovic, S. Inclusion and education in European countries. Final report: 10. Slovenia. Lepelstraat: DOCA Bureaus 2009 August.

[27] Skutnab Kangas T. Bilingualism or Not. The Education of Minorities. Clevedon: Multilingual Matters 1981.

[28] Working Committee on Quality Indicators. Sixteen quality indicators. European report on the quality of school education. Brussels: European Commisison, DG EAC 2000 May.

[29] Dronkers J., Roberts, P. School choice in the light of the effectiveness differences of various types of public and private schools in 19 OECD countries. J School Choice 2008; 2(3).

[30] Koenig M, Guchtenaire P. Political governance of cultural diversity. Democracy and human rights in multicultural societies. Paris: UNESCO Publishing 2007.

[31] Arnesen A, Bîrzea C, Dumont B, et al. Policies and practices for teaching sociocultural diversity. Report on the survey on initial education of teachers in sociocultural diversity. Strasbourg: Council of Europe Publishing 2008.

[32] Mesic M. Perspectives of multiculturalism - western and transitional countries. Zagreb: Croatian Commission for UNESCO 2004.

[33] Cluster "Teachers and Trainers". How can teacher education and training policies prepare teachers to teach effectively in culturally diverse settings? Report of the Peer Learning Activity, Oslo, May 2007. [Knowledge System for Lifelong Learning, www.kslll.net/Peer LearningActivities, retrieved on 2009 May 06].

[34] Necak Lük A. Language education for intercultural education in Slovenia. In: Ager D, Muskens G, Wright S, eds. Langauge education for intercultural communication. Clevedon: Multilingual Matters 1993; pp. 181-92.

[35] Manço A.A. Young people of immigrant origin in Europe: how can we make the school an instrument for social mobility and acquisition of intercultural competences. Achieving social cohesion in a multicultural Europe - concepts, situations and developments. Strasbourg: Council of Europe Publishing 2006.

[36] European Commission. Non-discrimination and equal opportunities: a renewed commitment. Community instruments and policies for Roma inclusion. Brussels: European Commission 2005 June.

[37] Mullis IVS, Martin MO, Robitaille DF, et al. TIMSS Advanced 2008 International Report: Findings from IEA's Study of Achievement in Advanced Mathematics and Physics in the Final Year of Secondary School. Chestnut Hill, MA: TIMSS \& PIRLS International Study Center, Boston College 2009.

[38] OECD. PISA 2006. Science competencies for tomorrow's world (two volumes). Paris: OECD 2007.

[39] EUROSTAT. Early school leavers by gender - Percentage of the population aged 18-24 with at most lower secondary education and not in further education or training. [http://epp.eurostat.ec.europa.eu/tgm/ table.do? tab $=$ table\&init $=1 \&$ language $=$ en $\&$ pcode $=$ tsisc $060 \&$ plugin $=1$, retrieved on 2009 July 27].

[40] Eurostat. Eurostat structural indicators quality profile: youth education attainment level. Luxembourg: EUROSTAT 2006 October.

[41] Muskens G. Inclusion and education in European countries: methodological considerations. in: Quality and Quantity, in press.

[42] INCLUD-ED. INCLUD-ED: Strategies for inclusion and social cohesion in Europe from education. [cited 2009 May 05].

[43] Muskens G. Inclusion and education in European countries. Final report: 3. Discussion and recommendations. Lepelstraat: DOCA Bureaus 2009 August.

[44] Council of Europe, European Court of Human Rights, Grand Chamber. judgement in the case of d.h. and others v. The Czech Republic (Application no. 57325/00), 2007 November 17. 